\title{
Are there Monthly Variations in Water Quality in the Amman, Zarqa and Balqa Regions, Jordan?
}

\author{
Khaled A. Alqadi*, Lalit Kumar \\ Ecosystem Management, School of Environmental and Rural Science, Faculty of Arts and Sciences, \\ University of New England, Armidale, NSW 2351, Australia \\ Email: "kalqadi@une.edu.au
}

Received 2013

\begin{abstract}
This study investigated the monthly variation of water quality in the Amman-Zarqa and Balqa regions in Jordan in terms of $\mathrm{pH}$, ammonium, nitrate and conductivity. During 2004 there was no monthly variation in water quality for most of the tested parameters. All readings were above the accepted range except for $\mathrm{pH}$, indicating that land use does have an impact on water quality irrespective of urban, industrial or agricultural usage. The water quality remained for the most part below the maximum levels for drinking standards in Jordan, but these standards are often below the WHO recommendations. The $\mathrm{pH}$ was found to fluctuate through the year. Nitrate levels were highly seasonal in irrigated lands but remained stable over basin covered by other land uses. Ammonium levels were high in areas of urbanisation and intensive animal husbandry as a consequence of effluent infiltration, peaking during the wet season due to increased infiltration. These results indicate that, over an annual cycle, the variation in water quality remains constant; however the continued drawdown of the aquifer system will inevitably lead to deterioration in the parameters investigated.
\end{abstract}

Keywords: Water Quality; pH; Ammonium; Conductivity; Nitrate

\section{Introduction}

The water crisis in Jordan is a major geopolitical issue that threatens the future and stability of the whole country. The Amman, Zarqa and Balqa regions supply irrigation water to an estimated 33,000 Ha, however, most of demand is for domestic and industrial water with the basin supplying over half of the population of Jordan with water [3]. Agricultural production in the basin is dominated by grazing, with only limited olive and fruit trees and the production of cereals near areas of permanent water.

Ground water quality has a major impact on human welfare and affects all human activity [7]. Understanding changes in ground water quality allows for effective management of water resources in the face of increasing pressures from urbanization, agricultural and industrial development [15]. However, Jordan is faced with a lack of funding to maintain monitoring which has resulted in fragmented data sets [13]. The utilisation of aquifers has led to severe lowering of the ground water table and this has changed the ground water chemistry [10]. The Amman, Zarqa and Balqa regions is renewable and draws water from areas of urban and industrial development and landfill sites and therefore is at significant risk of

${ }^{*}$ Corresponding author. waste water infiltration pollution [1].

Data from 2002 indicates that there was an unsustainable drawdown of ground water from the Amman-Zarqa Basin. In 2002 a total of $84 \mathrm{mcm}_{\text {year }}{ }^{-1}$ was withdrawn from the aquifer for municipal supply, while $54 \mathrm{mcm}$ year $^{-1}$ was taken to supply the agricultural sector. This represents an excess of $72 \mathrm{mcm}$ year $^{-1}$ of water above the estimated safe yield of $65 \mathrm{mcm}$ year $^{-1}$. This overdrawing from the 772 officially registered wells has led to a fall in the ground water table and declines in water quality [13]. Salameh [19] argued that the current drawdown of the aquifers has led to permanent damage of the hydrological system, and Al-Mahamid [4] argued that at current extraction rates areas in the middle of the basin will be completely dry in the next few decades. These findings were supported by Dottrige and Jaber [8] who argued that at current levels of extraction many of the aquifers dependent upon for urban and industrial supply will be dry by the middle of the twenty first century. The aim of this paper is to examine the water quality over an annual cycle in the Amman, Zarqa and Balqa regions under differing land use.

\section{Hydrogeology of the Amman-Zarqa Basin}

The geology of the Amman-Zarqa Basin is primarily 
sedimentary with ages ranging from the lower Cretaceous to the present (Table 1). The major aquifers in the Amman-Zarqa Basin from which water is drawn are considered to be hydraulically connected, but maybe separated in regions by geological layers which act as aquicludes [9].

There are three aquifer systems in the Amman-Zarqa Basin. There is evidence that water moves between the aquifers along the Zarqa fault system [4]. The upper aquifer is contained within the linked Campanian Amman (B2) and Turonian Wadi Sir (A7) limestone formations and the neighbouring basalt strata (V). The middle aquifer is contained within the Cenomanian Shue mar (A4) limestone formation. The lower aquifer is contained within the Albian-Aptian Kurnub (K) sandstone formation. Table 2 provides an overview of the hydrology and hydrochemistry of the three aquifers. The long term effects of drawdown has resulted in declines in the water table in all aquifers contained within the basin and this has led to an increase in the level of dissolved chemicals

Table 1. The geology and hydrogeology classification of the Amman-Zarqa Basin [18].

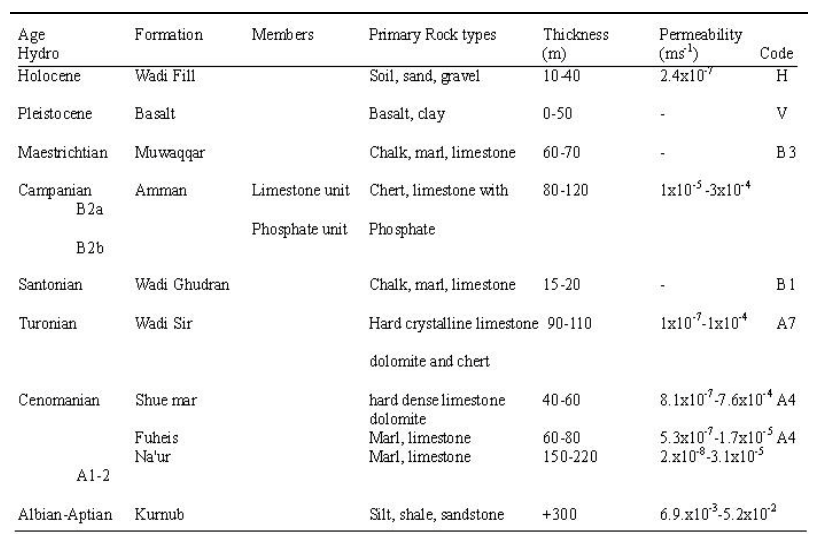

Table 2. The average hydrological and hydrochemical data for the three major aquifers in the Amman-Zarqa Basin for the period 1995-2003 [4].

\begin{tabular}{|c|c|c|c|}
\hline Parameters & Upper Aquifer & Middle Aquifer & Lower Aquifer \\
\hline Hydro code & $\mathrm{B} 2 / \mathrm{A} 7, \mathrm{~V}$ & A4 & $\mathrm{K}$ \\
\hline Transmissivity $\left(\mathrm{m}^{2} \mathrm{~d}^{-1}\right)$ & 0.38 to 38 & 9.6 to 117 & 1 to 146 \\
\hline Number of springs & 4 & 54 & 35 \\
\hline Spring Discharge $\left(10^{6} \mathrm{~m}^{3}\right)$ & 4 & 9 & 1.5 \\
\hline Confinement & Phraetic/Confined & Confined & Phraetic/Confined \\
\hline Annual abstraction $\left(10^{6} \mathrm{~m}^{3}\right)$ & 113.1 & 12.6 & 7.5 \\
\hline$\%$ of Water supply & 81.6 & 9.1 & 5.4 \\
\hline Number of wells & 456 & 63 & 81 \\
\hline Est Annual Ave change in water table (m) & -1 to -1.5 & -0.5 to -9 & -0.5 to -0.8 \\
\hline \multicolumn{4}{|l|}{ Ave Chemical Composition } \\
\hline $\mathrm{Ca}\left(\mathrm{mgL}^{-1}\right)(\mathrm{Mean} / \mathrm{Max}-\mathrm{Min})$ & $92.7 / 24.3-192.5$ & $72.3 / 51.7-94.6$ & $66.8 / 41.7-83.4$ \\
\hline $\mathrm{Mg}\left(\mathrm{mgL} L^{-1}\right)(\mathrm{Mean} / \mathrm{Max}-\mathrm{Min})$ & $49.27 .5-129$ & $34.9 / 22.5-46.1$ & $32.4 / 23.144 .5$ \\
\hline $\mathrm{Na}\left(\mathrm{mgL}^{-1}\right)$ (MeanMax-Min) & $163.4 / 25.5-422.1$ & $44.1 / 19.3-79.6$ & $59.2 / 20.5-117.1$ \\
\hline $\mathrm{K}\left(\mathrm{mgL}^{-1}\right)(\mathrm{Mean} / \mathrm{Max}-\mathrm{Min})$ & $8.2 / 2-15.6$ & $2.8 / 0-7.4$ & $4.7 / 1.6-9.4$ \\
\hline $\mathrm{HCO}_{3}\left(\mathrm{mLL}^{-1}\right)$ (MeanMax-Min) & $211.5 / 66.5-366$ & $290.3 / 248 \cdot 9-372$ & $257.1 / 133-321.5$ \\
\hline $\mathrm{SO}_{4}\left(\mathrm{mgL}^{-1}\right)(\mathrm{Mean} / \mathrm{Max}-\mathrm{Min})$ & $108.5 / 17.3-495.4$ & $33.5 / 15.4-65.3$ & $67.2 / 24.5-204.8$ \\
\hline $\mathrm{Cl}\left(\mathrm{mgL}^{-1}\right)(\mathrm{Mean} / \mathrm{Max}-\mathrm{Min})$ & 338.4443.3-958.5 & $89.5 / 27.3-163.3$ & $92.4 / 42.6-204.8$ \\
\hline $\mathrm{NO}_{3}\left(\mathrm{mgL} L^{-1}\right)(\mathrm{Mean} / \mathrm{Max}-\mathrm{Min})$ & $46.8 / 3.5-107.2$ & $33.0 / 7.7-66.9$ & $26.0 / 5.8-80$ \\
\hline $\mathrm{EC}\left(\mu \mathrm{Scm}^{-1}\right)(\mathrm{Mean} / \mathrm{Max}-\mathrm{Min})$ & $1679 / 500-3680$ & $830.5 / 536-1176$ & $818.1 / 650-1211$ \\
\hline $\mathrm{pH}$ (Mean/Max-Min) & $7.4 / 6.2-8.5$ & $7.7 / 7.3-7.9$ & $7.5 / 6.4-8.0$ \\
\hline
\end{tabular}

that are naturally occurring as a consequence of the surrounding geological formations of each aquifer [4]. As a consequence of the geological formations in which the aquifers are contained, calcium and magnesium are the dominant cations, while bicarbonate is the dominant anion [6].

The rainfall over the Amman-Zarqa Basin is highly seasonal. Peak rainfall occurs during late autumn to early spring with summer receiving negligible to no rainfall reflected in the annual runoff (Figure 1). The annual depth of rainfall over the basin is variable, ranging from $50 \mathrm{~mm}$ in the east to $1000 \mathrm{~mm}$ in the west; however the total annual rainfall for the region has declined over the last three decades by 25 - 33 mm [4]. This has an impact on the total runoff potential and the water available for recharging of the aquifers within the basin. During the period of rainfall the B2/A7 aquifer is subjected to infiltration which then enters the connected A4 aquifer through fracture zones as the water flows north easterly down the Amman-Zarqa sincline [6].

\section{Description of Study Area}

The Amman, Zarqa and Balqa regions cover an area of $1939 \mathrm{~km}^{2}$ and are located in north eastern Jordan uplands and are between $500-1000 \mathrm{~m}$ in elevation with an annual precipitation of 150 to $600 \mathrm{~mm}_{\text {year }^{-1}}$ [13,17]. Figure 2 illustrates the study area and location of the study area within Jordan. The basin contains significant population and industrial production centres. Agriculture is primarily restricted to plains of the water courses with rangelands dominating the remainder. The sporadic distribution of population and industry, as well as the restriction of agriculture to the water courses has been that the spatial quality of the ground water is highly variable with aquifer systems [5].

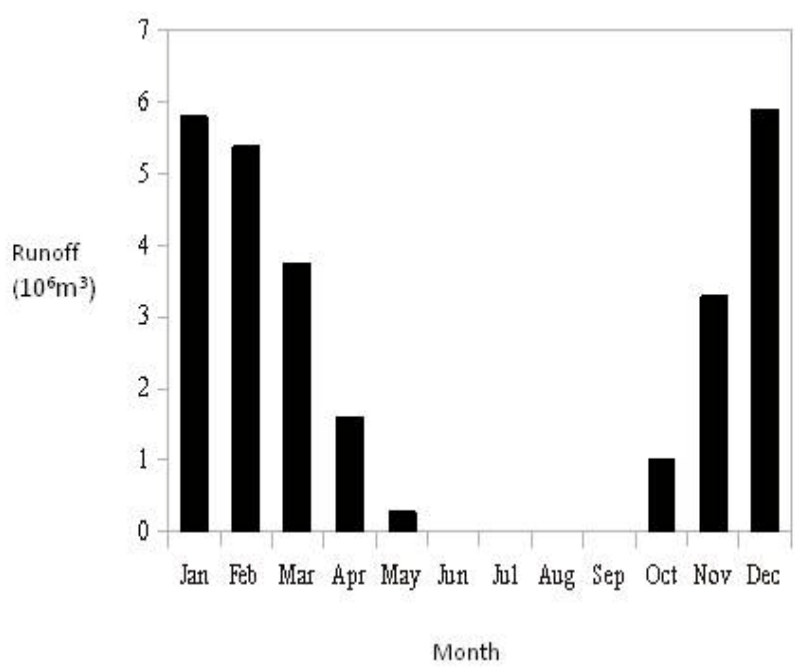

Figure 1. The monthly long-term rainfall average of the AmmanZarqa Basin for the period 1970-2002. 


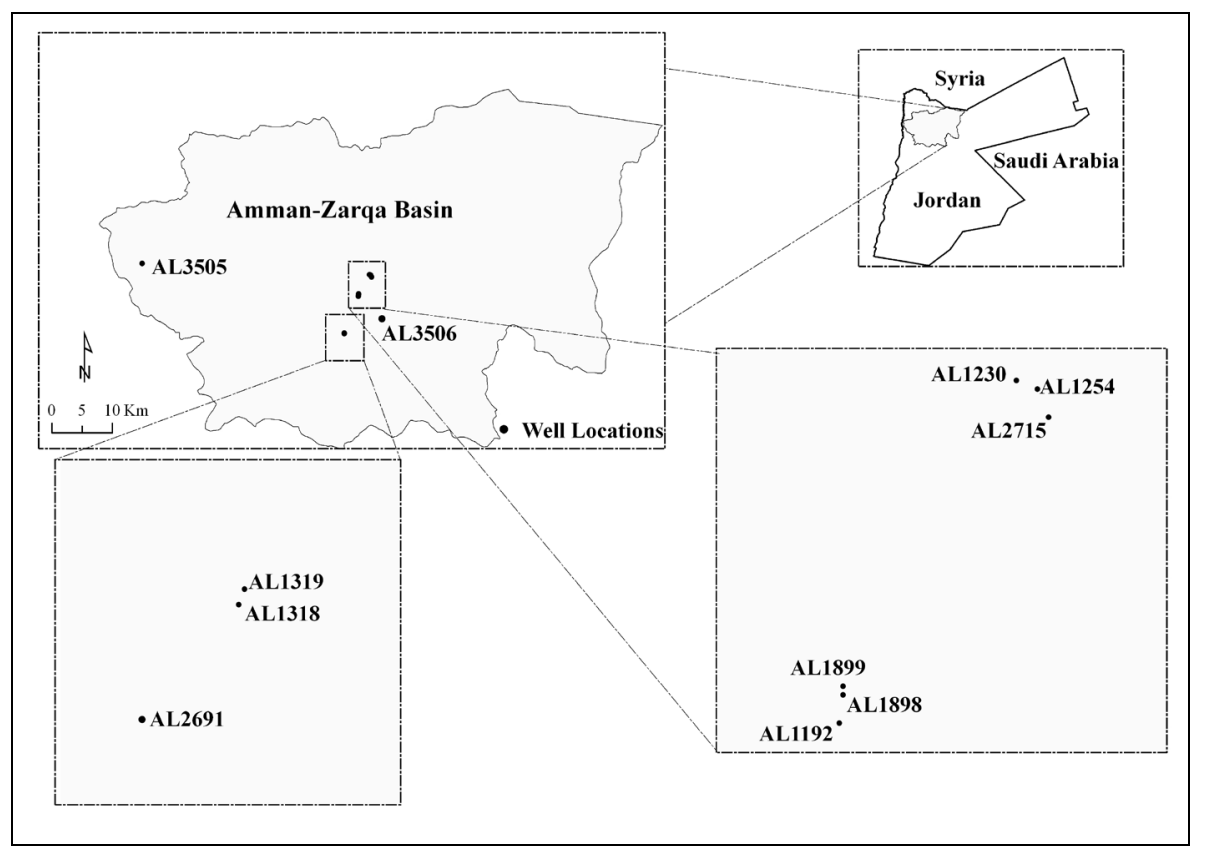

Figure 2. The location of the Amman, Zarqa and Balqa regions and the location of the wells investigated in this study.

\section{Methods}

The use of geographic information systems has proven to be an effective means of investigating spatial changes in water quality $[7,15]$. The spatial data support system, Arc View GIS, provides the tools to allow the seasonal mapping of temporal changes in water quality parameters [16]. The use of mapping systems in conjunction with aerial images allows for a greater understanding of the potential impacts of land use on water quality.

Historical data for wells in the Amman, Zarqa and Balqa regions were obtained from the Jordan Water Authority. From these historical records on the water quality, 11 wells from the three regions representing each of the three major aquifers, and with significantly detailed monthly data for 2004, were selected for investigation (Table 3). From the records of these 11 wells the monthly recorded conductivity, ammonium, nitrate and $\mathrm{pH}$ were graphed to determine if seasonal variation in water quality parameters could be determined. A map of the Amman-Zarqa Basin was digitised using Arc Map 9.3 and the location of the 11 wells plotted. Rainfall data for the area surrounding the wells in 2004 was also mapped. The depth of the wells was also investigated to determine the geological formation that contained and surrounded the wells, and this enabled an understanding of the influence of the surrounding strata on the quality of the water contained in the aquifer.

\section{Results}

The wells represent areas of five primary land uses. The well AL1230 is located in an area of heavy industrial use
Table 3. Identification, location and land use of the wells and surrounding areas used in this study.

\begin{tabular}{|c|c|c|c|c|c|c|c|}
\hline Well $\mathbb{D}$ & Well Name & $\begin{array}{l}\text { Coordina } \\
\text { Palestine }\end{array}$ & & $\begin{array}{l}\text { Land } \\
\text { Use }\end{array}$ & $\begin{array}{l}\text { Aquif } \\
\text { depth }\end{array}$ & if Altitude & $\begin{array}{c}\text { Hydro } \\
\text { Code }\end{array}$ \\
\hline & & North $(\mathrm{kn}$ & n) East(km) & & (m) & (masl) & \\
\hline AL1192 & New Municipality & 166.535 & 254.830 & Residential & 281 & 568 & A4 \\
\hline AL1230 & Hashiniya No. 3 & 170.130 & 256.690 & Heavy Industrial & 1102 & 540 & $\mathrm{~B} 2 / \mathrm{A} 7$ \\
\hline AL1254 & Hashiniya No. 5 & 170.040 & 256.910 & Irr. Agricultural & 106 & 540 & ALL \\
\hline AL1318 & Awajan 22 & 160.340 & 252.468 & Med. Industrial & - & 587 & $\mathrm{~B} 2 / \mathrm{A} 7$ \\
\hline AL1319 & Awajan 21 & 160.410 & 252.494 & Med. Industrial & 148 & 583 & $\mathrm{~B} 2 / \mathrm{A} 7$ \\
\hline AL1898 & Zerqa Well No. 3 & 166.830 & 254.870 & Residential & 246 & 587 & $\mathrm{~A} 4$ \\
\hline AL1899 & Zerqa Well No. 3 & 166.820 & 254.870 & Residential & 113 & 586 & $\mathrm{~B} 2 / \mathrm{A} 7$ \\
\hline AL2691 & Awajan 23 & 160.000 & 251.980 & Med. Industrial & 151 & 600 & $\mathrm{~B} 2 / \mathrm{A} 7$ \\
\hline AL2715 & Hashiniya No. 2 & 169.744 & 257.027 & Irr. Agricultural & 128 & 540 & $? \mathrm{~B} 2 / \mathrm{A} 7$ \\
\hline AL3505 & Dafali No. 3 & 172.011 & 218.905 & Grazing & 332 & 615 & $\mathrm{~A} 4$ \\
\hline AL3506 & Supply No.4 & 162.750 & 256.900 & Irr. Agricultural & $500+$ & 491 & $\mathrm{~K}$ \\
\hline
\end{tabular}

on the edge of a water course. The three wells AL1192, AL1898 and AL1899 are surrounded by residential areas; however there is a chicken farm nearby. The wells AL1254 and AL2715 are located on a small irrigation plain with a central water course surrounded by arid lands, while AL3505 is located in the nearby arid land. The three wells AL1318, AL1319 and AL2691 are all in light industrial with neighboring residential area, and are located near a water course, with AL1318 and AL1319 located in and around waste water treatment works. Figure 3 illustrates the aerial view of the wells and their surrounds.

This investigation also indicates that in areas of low development represented by AL 3505 and AL3506, there was a low level of nitrate contamination. These two wells draw water from the middle and lower aquifer systems 
indicating that there is a natural tendency for low nitrate levels from this supply in underdeveloped areas. One well, AL1254 had a high nitrate indicting infiltration and may represent the use of nitrate fertilisers on the irrigated plains on which the well was located. This infiltration diffused through the aquifers to which it is connected and the well nitrate level returned to that of all the study area for the upper and middle systems. The results also indicate that, while there is a peak in the $\mathrm{pH}$ of the wells in late spring and summer, however, there is little change throughout the year, with all wells having a $\mathrm{pH}$ between
7 to 8 . The ammonium level was only significantly raised in the residential areas, with all industrial and agricultural wells demonstrating an annual low ammonium level. The ammonium level in the residential areas peaked during the onset of the rains, indicating that there is a possible flushing of sewerage down into the water table from the individual dwellings septic systems and the nearby chicken farm. The peak in conductivity during the period of peak rainfall indicates that the infiltration of water through the geological strata is carrying dissolved salts into the aquifers.

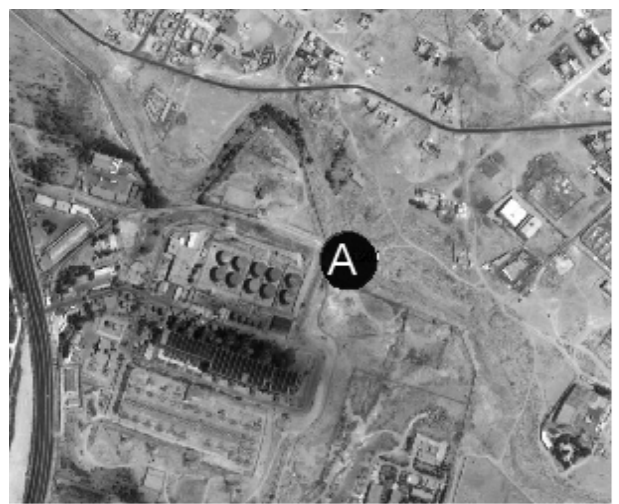

A- AL 1230

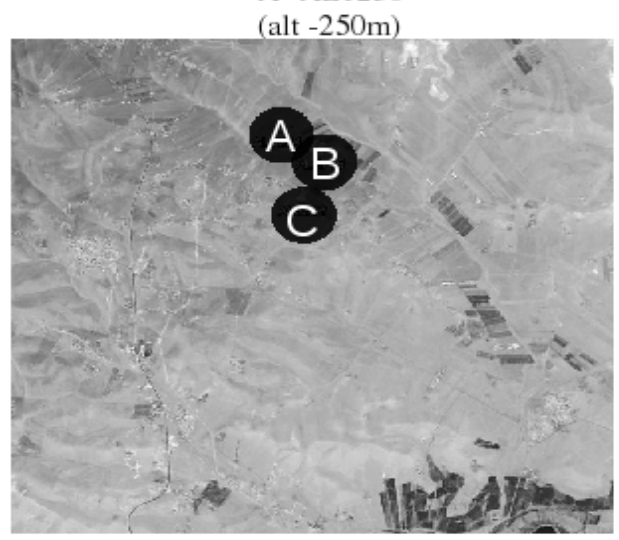

A-AL1254, B-AL2715, C-AL3506 (alt -1,500m)

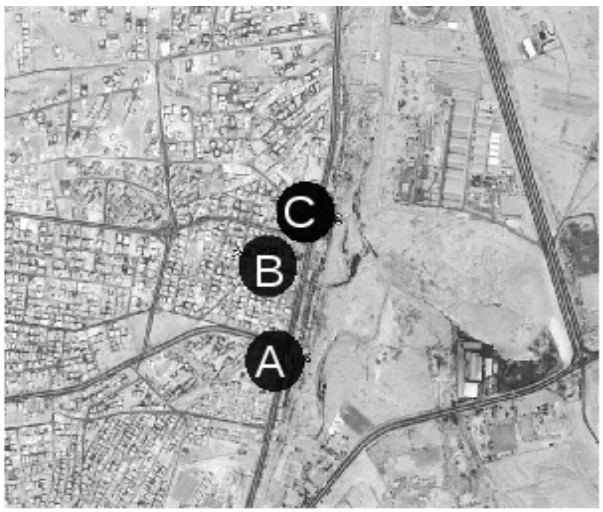

A-AL1192, B- AL1898, C- AL1899 (alt $-450 \mathrm{~m}$ )

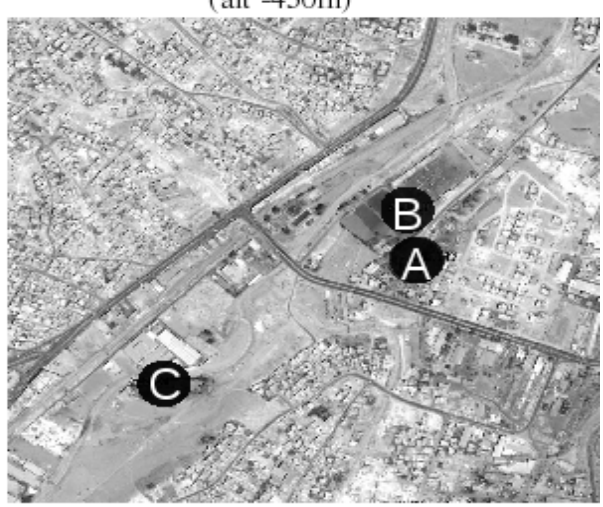

A-AL1318-B-AL1319, C-AL2691 (alt $-300 \mathrm{~m}$ )

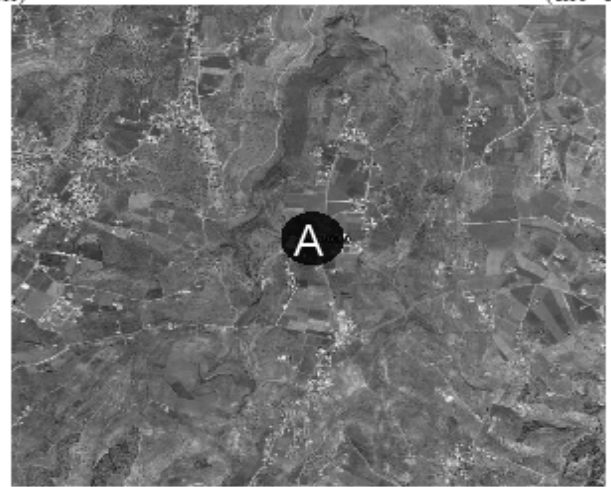

A- AL3505

(alt -900m)

Figure 3. Land use images showing surrounding areas of each well (from Google Earth, 2004). 


\section{1. $\mathrm{pH}$}

At present there is no considered risk to consumers from water $\mathrm{pH}$ levels, and therefore, no safe health guidelines [15]. However, the $\mathrm{pH}$ has significant impact on the operational water quality parameters with the World Health Organisation (WHO, 2004) recommending an optimum range of 6.5 - 9.5. The Jordan Water Standard indicates that the permissible $\mathrm{pH}$ range is 6.5 - 85 for drinking water $[4,11]$. The maximum and minimum $\mathrm{pH}$ for the 11 wells in the Amman, Zarqa and Balqa regions investigated ranged from 6.84 to 8.06 , respectively. This study determined that no well fell outside the operation water parameters of the WHO. Figure 4 illustrates the $\mathrm{pH}$ on a monthly basis for each of the wells investigated. The results indicate that there was a variation in the $\mathrm{pH}$ of the wells throughout the year of $\sim 1.2$ to $\sim 0.63$. Table 4 illustrates the maximum and minimum $\mathrm{pH}$ for each well and the month in which that level was reached. There is clear indication that water $\mathrm{pH}$ reaches a maximum during late spring to summer in all wells and with minimums reached in autumn, winter and early spring depending on the well.

Table 4. The pH for the maximal and minimal months and the percentage change over the period for the 11 wells.

\begin{tabular}{llllll}
\hline Well ID & \multicolumn{2}{l}{ Maximum } & \multicolumn{2}{l}{ Minimum } & Variation \\
& pH & Month & pH & Month & pH \\
\hline AL1192 & 8.01 & July & 6.84 & April & 1.17 \\
AL1230 & 7.71 & July & 6.89 & October & 0.82 \\
AL1254 & 8.06 & July & 7.19 & March & 0.87 \\
AL1318 & 7.85 & July & 7.08 & April & 0.77 \\
AL1319 & 7.82 & July & 6.96 & January & 0.86 \\
AL1898 & 7.84 & August & 7.11 & March & 0.73 \\
AL1899 & 7.82 & July & 6.97 & March & 0.85 \\
AL2691 & 7.76 & August & 7.07 & February & 0.69 \\
AL2715 & 7.78 & May & 7.10 & October & 0.68 \\
AL3505 & 7.79 & June & 7.16 & April & 0.63 \\
AL3506 & 7.99 & May & 7.33 & April & 0.66 \\
\hline & & & & &
\end{tabular}
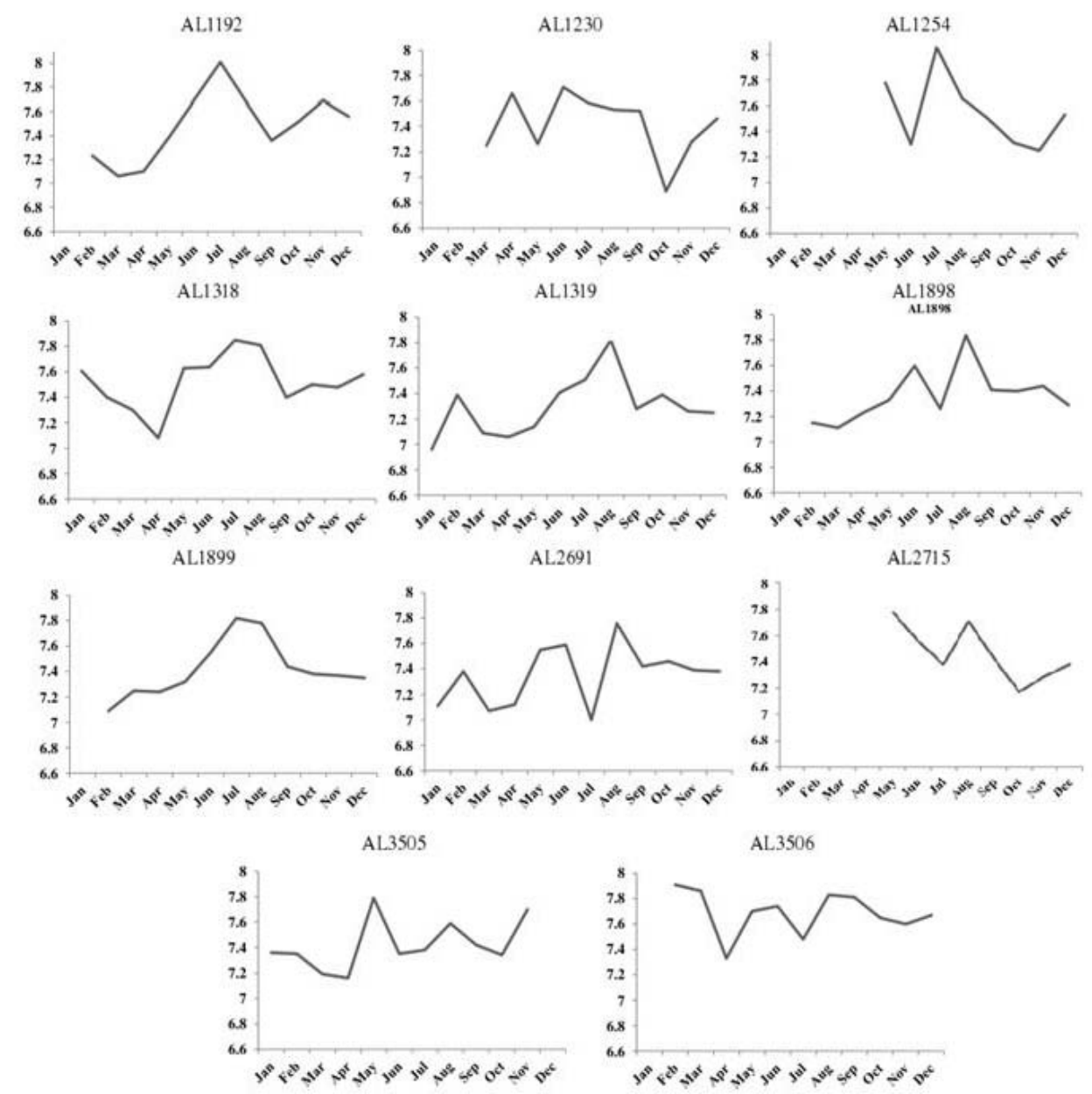

Figure 4. The pH records for each well in 2004. 


\subsection{Nitrate}

High nitrate levels can have significant negative health consequences [11]. The WHO guidelines indicate a maximum nitrate level of $50 \mathrm{mgL}^{-1}$ for drinking water; however while the authorities in Jordan recognize a permissible target level of $50 \mathrm{mgL}^{-1}$, the national standards allow for a concentration of up to $70 \mathrm{mgL}^{-1}$, [4]. The maximum and minimum nitrate levels for the 11 wells in the Amman, Zarqa and Balqa regions investigated ranged from $<0.16 \mathrm{mgL}^{-1}$ to $75.88 \mathrm{mgL}^{-1}$, respectively. The results of the investigation into the 11 wells found that only two of the wells (AL3505, AL3506) did not have year round dangerous nitrate levels making the water fit for consumption in WHO terms, with one other well (AL1318) being safe for only one month. However, the Jordan maximum permissible level for nitrate was only exceeded significantly in areas of irrigation (AL1254). Notwithstanding, the urban areas also contain significantly high levels of nitrates in the immediate wells. Figure 5 illustrates the nitrate level on a monthly basis for each of the wells investigated. The results indicate that there was a variation in the nitrate within each well throughout the year of $\sim 6 \mathrm{mgL}^{-1}$ to $\sim 50 \mathrm{mgL}^{-1}$. Table 5 highlights the nitrate variation throughout the year for each of the wells investigated. These results indicate significant variation in nitrate concentration in each well on a monthly basis with no specific seasonal variation evidenced.

Table 5. The Nitrate concentration $\left(\mathrm{mgL}^{-1}\right)$ for the maximal and minimal months and the percentage change over the period for each of the 11 wells.

\begin{tabular}{|c|c|c|c|c|c|}
\hline \multirow[t]{2}{*}{ Well ID } & \multicolumn{2}{|c|}{ Maximum } & \multicolumn{2}{|c|}{ Mirimum } & \multirow{2}{*}{$\begin{array}{l}\text { Variation } \\
\mathrm{mgL}^{-1}\end{array}$} \\
\hline & $\mathrm{mgL}^{-1}$ & Month & $\mathrm{mgL}^{-1}$ & Month & \\
\hline AL1192 & 74.60 & July & 62.00 & January & 12.60 \\
\hline AL1230 & 61.33 & July & 52.30 & October & 9.03 \\
\hline AL1254 & 104.65 & September & 55.93 & July & 48.72 \\
\hline AL1318 & 74.50 & January & 38.94 & August & 34.56 \\
\hline AL1319 & 68.00 & January & 52.75 & February & 15.25 \\
\hline AL1898 & 75.88 & April & 66.75 & January & 9.13 \\
\hline AL1899 & 73.05 & April & 54.43 & August & 18.62 \\
\hline AL2691 & 71.05 & November & 50.58 & February & 20.47 \\
\hline AL2715 & 63.32 & $\operatorname{May}\left(4^{\text {th }}\right)$ & 53.01 & $\operatorname{May}\left(31^{\text {th }}\right.$ ) & 10.31 \\
\hline AL3505 & 25.30 & January & 0.66 & February & 24.64 \\
\hline AL3506 & 6.53 & May & $<0.16$ & Feb., Mar., Sept. & 6.37 \\
\hline
\end{tabular}

AL1192

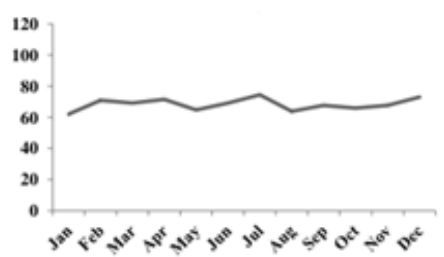

AL1318

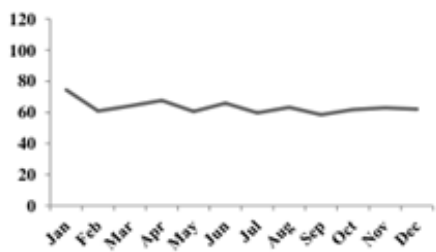

AL1899

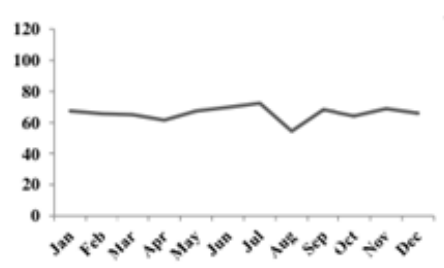

AL1230

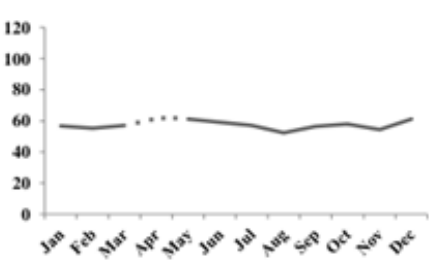

AL1319

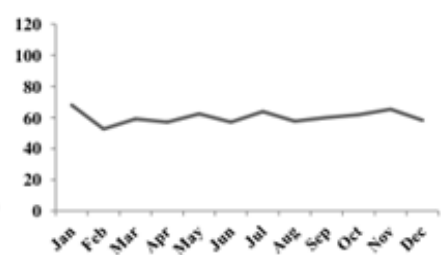

AL2691

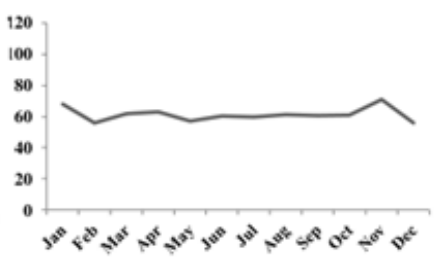

AL 3505
AL.1254

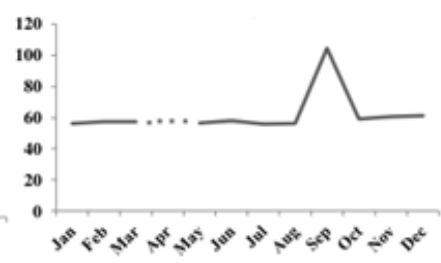

AL 1898

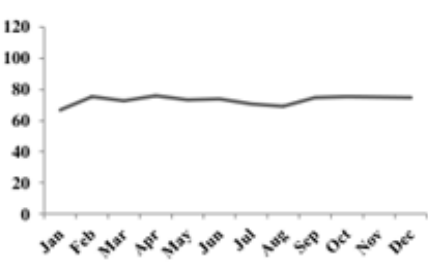

AL2715

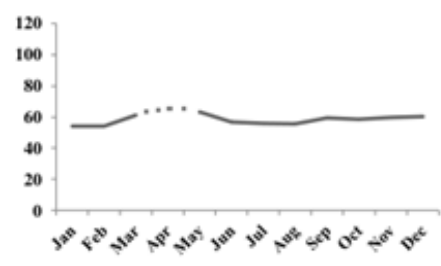

AL.3506
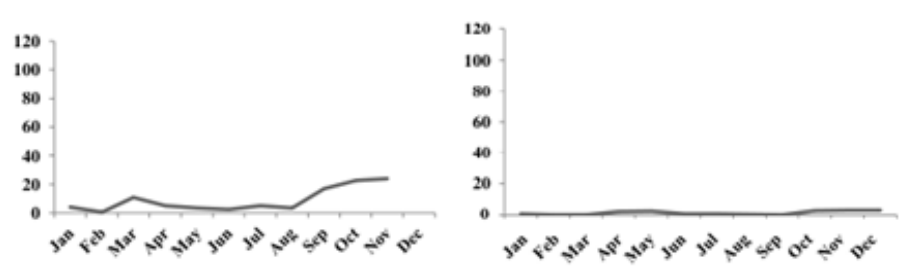

Figure 5. The Nitrate $\left(\mathrm{mgL}^{-1}\right)$ records for each well in 2004. 


\subsection{Ammonium}

The maximum and minimum ammonium $\left(\mathrm{NH}_{4}\right)$ levels for the 11 wells in the Amman, Zarqa and Balqa regions investigated ranged from $<0.05 \mathrm{mgL}^{-1}$ to $4.2 \mathrm{mgL}^{-1}$ respectively. Figure 6 illustrates the ammonium levels on a monthly basis for each of the wells investigated. The results indicate that there was a variation in the ammonium level within any one well throughout the year of $\sim 0.05 \mathrm{mgL}^{-1}$ to $3.41 \mathrm{mgL}^{-1}$. Table 6 highlights the ammonium variation throughout the year for each of the wells investigated. These results indicate that only three wells (AL1192, AL1898, and AL1899) showed significant variation in nitrate concentration with all the other wells having an ammonium level of below $\sim 0.1 \mathrm{mgL}^{-1}$ throughout the year. Ammonium levels tended to rise towards the end of each year with the first months showing the lowest concentrations; however, the three wells with significantly higher ammonium levels (AL1192,
AL1898, AL1899) showed the reverse with higher concentration during the first three months of the year.

Table 6. The Ammonium $\left(\mathrm{NH}_{4} \mathrm{mgL}^{-1}\right)$ for the maximal and minimal months and the percentage change over the period.

\begin{tabular}{llllll}
\hline Well ID & \multicolumn{2}{c}{ Maximum* } & \multicolumn{2}{c}{ Minimum* } & Variatio \\
& Conc. & Month & Conc. & Month & Conc. \\
\hline AL1192 & 3.62 & January & 1.55 & December & 2.07 \\
AL1230 & $<0.10$ & Oct., Nov., Dec. & $<0.05$ & Jan., Mar., Apr. & $\sim 0.05$ \\
AL1254 & $<0.10$ & Oct., Nov., Dec. & $<0.05$ & Jan.-May & $\sim 0.05$ \\
AL1318 & $<0.10$ & Oct., Nov., Dec. & $<0.05$ & Feb.-May & $\sim 0.05$ \\
AL1319 & $<0.10$ & Oct., Nov., Dec. & $<0.05$ & Mar., Apr., May & $\sim 0.05$ \\
AL1898 & 4.16 & February & 0.75 & January & 3.41 \\
AL1899 & 2.45 & May & 1.01 & April & 1.44 \\
AL2691 & $<0.10$ & Sept.- Dec & $<0.05$ & Feb.-May & $\sim 0.05$ \\
AL2715 & $<0.10$ & Oct, Nov, Dec. & $<0.05$ & Jan., Mar., Apr. & $\sim 0.05$ \\
AL3505 & $<0.10$ & Oct, Nov., Dec. & $<0.05$ & Jan. -May & $\sim 0.05$ \\
AL3506 & $<0.10$ & Oct, Nov, Dec. & $<0.05$ & Jan.,-May & $\sim 0.05$ \\
\hline
\end{tabular}

*Partial result with data from some months unavailable.

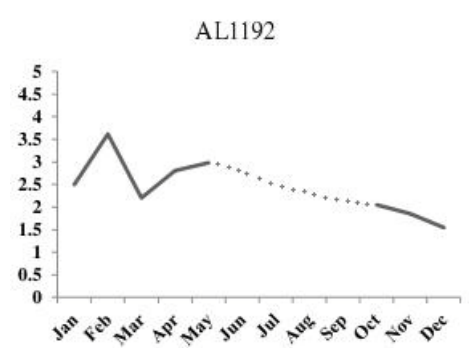

AL1318

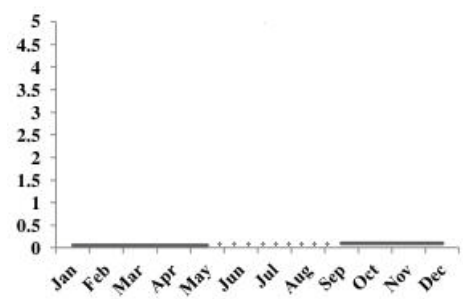

AL1899

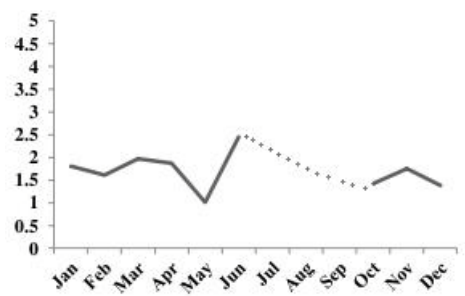

AL1230

AL1254

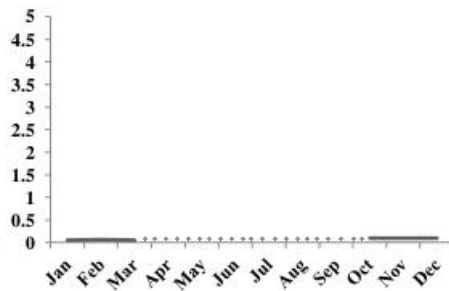

AL1319

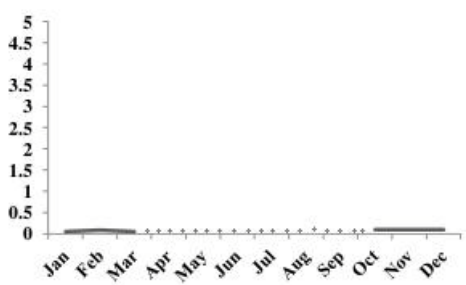

AL1898

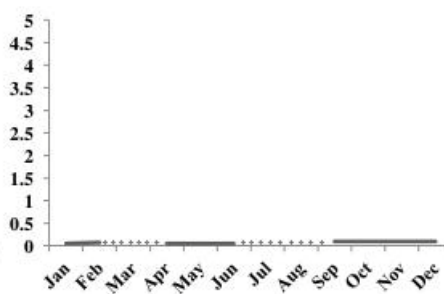

AL2691

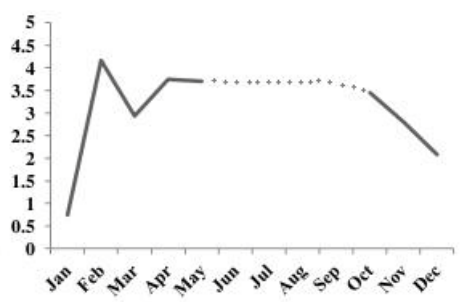

AL2715
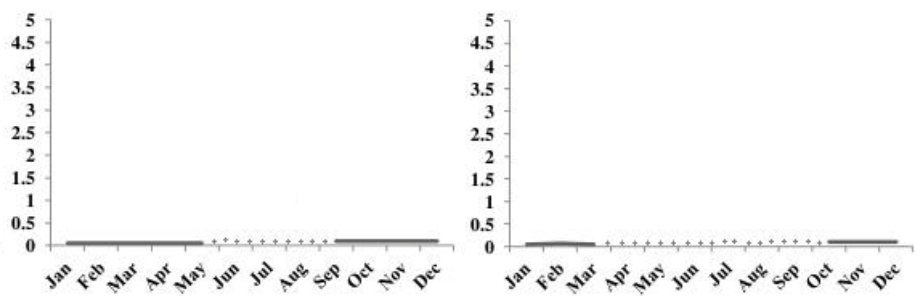

AL3505

AL 3506
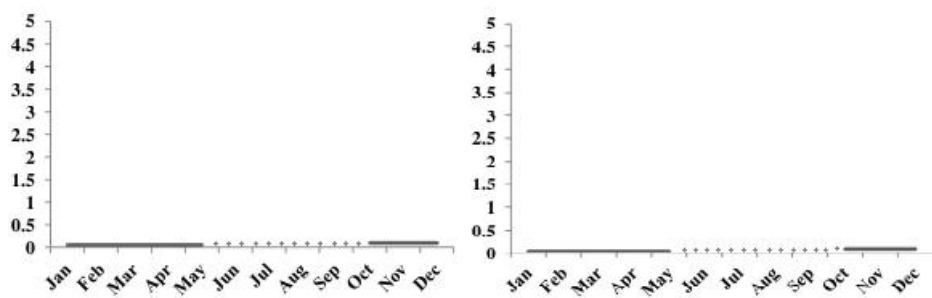

Figure 6. The ammonium $\left(\mathrm{NH}_{4} \mathrm{mgL}^{-1}\right)$ records for each well in 2004 with inferred data shown as a dotted line. 


\subsection{Conductivity}

The maximum and minimum conductivity levels for the 11 wells in the Amman, Zarqa and Balqa regions investigated ranged from $790 \mu \mathrm{Scm}^{-1}$ to $3640 \mu \mathrm{Scm}^{-1}$, respectively. Figure 7 illustrates the conductivity level on a monthly basis for each of the wells investigated. The results indicate that there was a variation in the conductivity within any one well throughout the year of 276 $\mu \mathrm{Scm}^{-1}$ to $1935 \mu \mathrm{Scm}^{-1}$. Table 7 highlights the monthly conductivity throughout the year for each of the wells investigated. These results indicate the early months of the year have the lowest conductivity; however this rises rapidly during May through June. These results also demonstrate that the conductivity within a well can change significant within any month with AL1192 showing a $145 \%$ rise in conductivity between the $4^{\text {th }}$ April and $27^{\text {th }}$ May.

Table 7. The conductivity for the maximal and minimal months and the percentage change over the period for each of the 11 wells.

\begin{tabular}{|c|c|c|c|c|c|}
\hline \multirow[t]{2}{*}{ Well ID } & \multicolumn{2}{|c|}{ Maximum } & \multicolumn{2}{|c|}{ Mirimum } & \multirow{2}{*}{$\frac{\text { Variation }}{\mu \mathrm{Scm}^{-1}}$} \\
\hline & $\mu \mathrm{Scm}^{-1}$ & Month & $\mu \mathrm{Scm}^{-1}$ & Month & \\
\hline$\overline{\mathrm{AL} 1192}$ & 3110 & May & 1175 & April & 1935 \\
\hline AL1230 & 3510 & June & 2800 & Jan. Feb. & 710 \\
\hline AL1254 & 3630 & June & 2890 & January & 740 \\
\hline AL1318* & 2290 & March & 1731 & February & 559 \\
\hline AL1319* & 2140 & March & 1656 & February & 484 \\
\hline AL1898 & 3310 & May & 2960 & November & 350 \\
\hline AL1899 & 3370 & May & 2868 & July & 502 \\
\hline AL2691* & 1886 & March & 1408 & Feb. Mar. & 478 \\
\hline AL2715 & 3640 & June & 2910 & January & 730 \\
\hline AL3505* & 1845 & March & 967 & January & 878 \\
\hline AL3506 & 1066 & March & 790 & January & 276 \\
\hline
\end{tabular}

*Well subject to chlorination during some months.

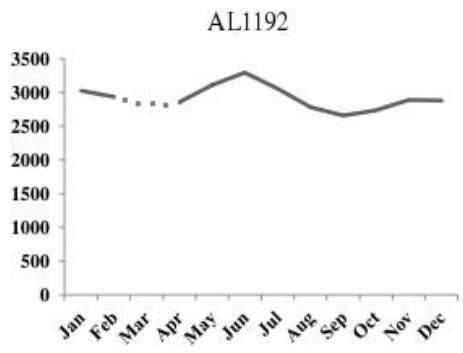

AL1318

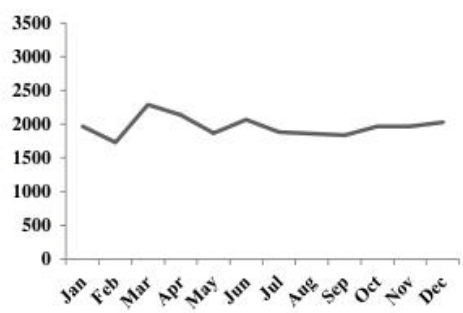

AL1899

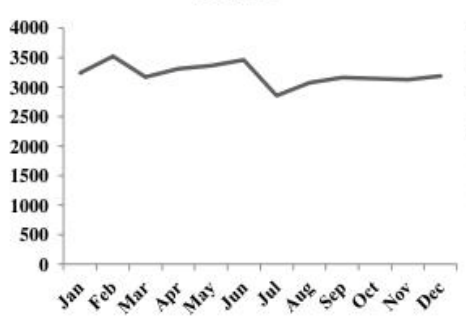

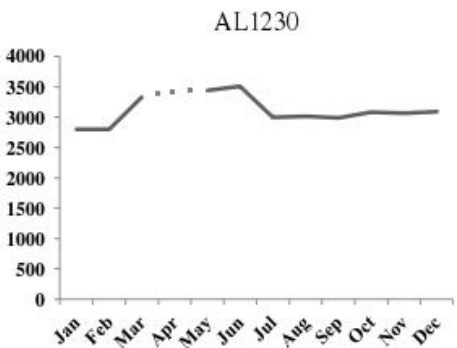

AL1319

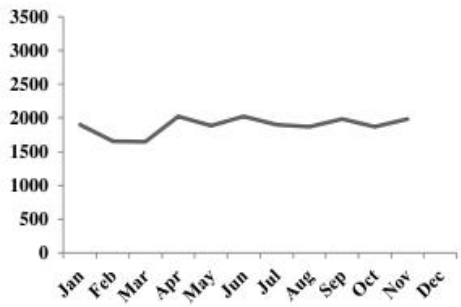

AL2691

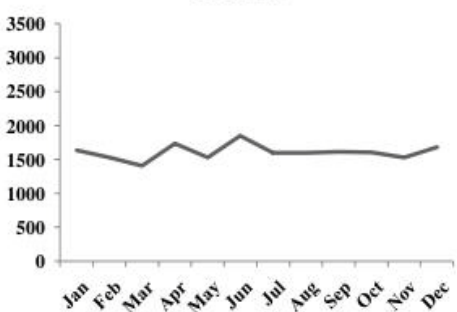

AL3505

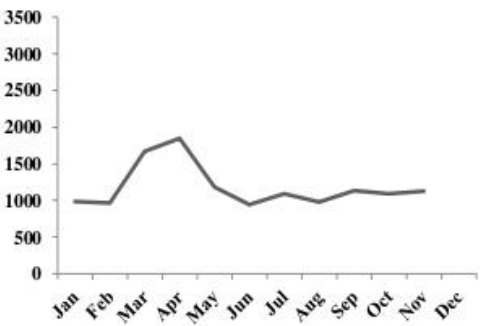

AL1254
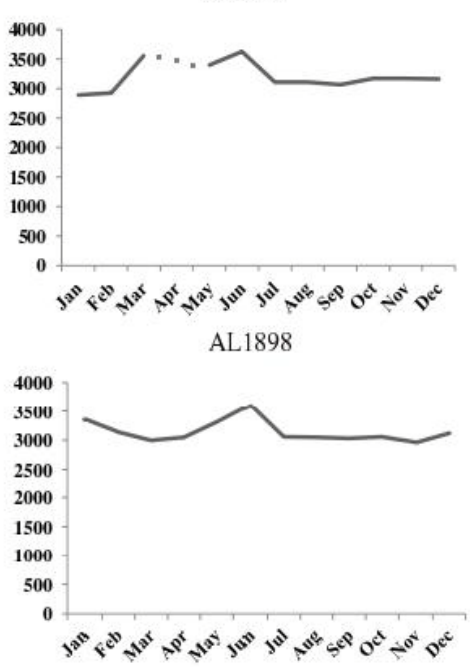

AL2715

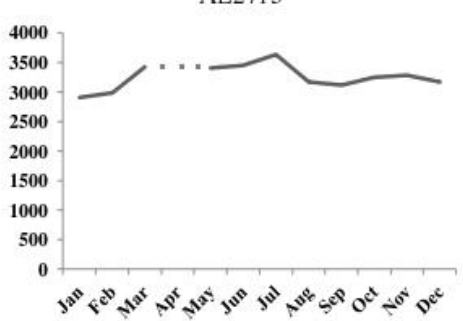

AL3506

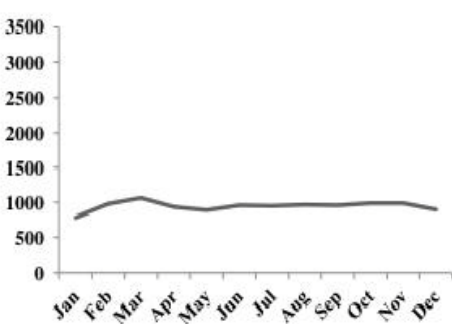

Figure 7. The conductivity $\left(\mu \mathrm{Scm}^{-1}\right)$ records for each well in 2004 with inferred data shown as a dotted line. 


\section{Discussion}

This study confirmed waste effluent can have a significant negative impact on the water quality of the aquifers in the basin. However, this study indicates that the problem may come from urban areas with low sanitation infrastructure. Also, areas under irrigation can have a marked, localised and temporary effect on water quality. Infiltration is areas of underdevelopment have significant increase in the conductivity, particularly as the first flush from the rains moves through the profile. Notwithstanding all aquifers were determined to comply with the guidelines for maximum permissible standards for drinking water, except for the A2/B7 aquifer from which water is drawn has regions of conductivity which is outside these standards. It must be noted that the maximum permissible level for most water contaminants in Jordan often exceed the WHO recommendations [4].

During this study the $\mathrm{pH}$ of all wells remained within the permissible standards of the Jordanian water authority [4]. This study concluded that irrigation can have a significant impact on the nitrate level of the aquifer with nitrate levels shown to significantly exceed the maximal permissible levels [4]. Areas of high urban density also had higher nitrate levels which seasonally peaked at or just above the Jordan Governmental standards for the maximum permissible level, while lands which are grazed have the lowest nitrates [4]. The high ammonium content of AL1192, AL1898, and AL1899 is postulated to come from infiltration of the effluent from the chicken farm, indicating that ammonium contamination is highly dependent on land use. The conductivity was found to be lowest in the rangelands with irrigated, urban, and industrial lands showing the highest readings. This reflects the level of water use in each of these areas, indicating that drawdown has a negative impact on the conductivity of the water. This study confirms the results obtained in neighboring aquifer systems in Jordan that indicate that urbanization and industrialization, coupled with intensive agriculture, have a negative impact on water quality when compared to natural rangeland systems [2,10].

Many of the aquifer systems in Jordan are under threat from overexploitation and this unsustainable drawdown will lead to many systems becoming dry by 2030 to 2040 [8].There is a need for increased monitoring throughout the Amman, Zarqa and Balqa regions over a long term in order to capture a more reliable image of the declines in water quality and regulate the water extraction or face the loss of the aquifer system $[4,13,18]$.

\section{Conclusions}

The aquifers within the Amman, Zarqa and Balqa regions are affected by irrigation, industrialisation and urbansiation. The increased drawdown of the aquifers has led to declines in the water quality over the long term. The monthly variations in water quality parameters are signifcantly affected by the rainfall which leads to infiltration of water that carries pollutants from anthropogenic sources and dissolved salts from the geological strata that the water moves through. The drawdown of the aqufers has led to a concentration of salts and other contaminants that would have previously been dispersed in a historical larger water volume.

\section{REFERENCES}

[1] M. Al-Farajat, I. Hamdan, K. Jaber, and S. H. Mohammed, "GIS Mapping of Ground Water Vulnerability against Pollution in Amman Using DRASTIC dex, "Hydrogeologie und Umwelt, Vol. 33, No. 9, 2005, pp. 1-19.

[2] A. Al-Hanbali and A. Kondoh, "Ground Water Vulnerability Assessment and Evaluation of Human Activity Impact (HAI) within the Dead Sea Groundwater Basin, Jordan," Hydrogeology Journal, Vol.16, 2008, pp. 499-510. doi:10.1007/s10040-008-0280-7

[3] E. K. Al-Karablieh, A. S. Jabarin and M. A. Tabieh, "Jordan Horticultural Export Competitiveness from Water Perspective," Journal of Agricultural Science and Technology, Vol. B1, 2011, pp. 964-974.

[4] J. Al-Mahamid, "Integration of Water Resources of the Upper Aquifer in Amman-Zarqa Basin Based on Mathematical Modeling and GIS, Jordan,” Freiberg Online Geology, Vol. 12, 2005, pp. 7-223.

[5] Al-Mashagbah, R. Al-Adamat, and E. Salmeh, "The Use of Kriging Techniques with in GIS Environment to Investigate Groundwater Quality in the Amman-Zarqa Basin/Jordan,” Research Journal of Environmental and Earth Sciences, Vol. 4, No 2, 2011, pp. 177-185.

[6] E. Al-Tarazi, J. A. Rajab, A. Al-Naqa and M. El-Waheidi, "Detecting Leachate Plumes and Groundwater Pollution at Ruseifa Municipal Landfill Utalising VLF-EM Method," Journal of Applied Geophysics, Vol. 65, 2008, pp. 121-131. doi:10.1016/j.jappgeo.2008.06.005

[7] P. Balakrishnan, A. Saleem and N. D, "Mallikarjan, Groundwater Quality Mapping Using Geographic Information System (GIS): A Case Study of Gulbarga City, Karnataka, India," African Journal of Environmental Science and Technology, Vol.5, No. 12, 2011, pp. 1069-1084. doi:10.5897/AJEST11.134

[8] J. Dottridge and N. A. Jaber, "Groundwater Resources and Quality in Northeastern Jordan: Safe Yield and Sustainability," Applied Geography, Vol. 19, pp. 313-323. doi:10.1016/S0143-6228(99)00012-0

[9] A. El-Naqa, N. Hammouri and M. Kuisi, "GIS- Based Evaluation of Groundwater Vulnerability in the Russeifa Area Jordan,” Revista Mexicana de Ciencias Geológicas, Vol. 23, 1999, pp. 277-287.

[10] N. Hammouri and A. El-Naqa, "GIS Based HydroGeological Vulnerability Mapping of Ground Water Resources in Jerash Area- Jordan,” Geofísica Internacional, 
Vol. 47, No. 2, 2008, pp. 85-97.

[11] P. F. Hudak, "Regional Trends in Nitrate Content of Texas Groundwater,” Journal of Hydrology, Vol. 228, 2000, pp. 37-47. doi:10.1016/S0022-1694(99)00206-1

[12] Jordanian Institute of Standards and Metrology (JISM) Drinking water standards No. (286/2001), 2001, Government of Jordan, Amman.

[13] Jordan Ministry of Water and Irrigation (JMWI). DisiMudawarra to Amman Water Conveyance System: Environmental and Social Management Plan Part 2. 2009, Government of Jordan, Amman.

[14] G. Jousma, Guideline on: Groundwater Monitoring for General Reference Purposes. International Working Group I, International Groundwater Resources Assessment Centre, Utracht, GP 2008-1, 2008.

[15] R. T. Mehrjardi, M. Z. Jahromi, S. Hahmodi and A. Hei- dari, "Spatial Distribution of Groundwater Quaity and Geostatistics (Case Study: Yazd-Ardakan Plain)," World Applied Sciences Journal, Vol. 4, No. 1, 2008, pp. 9-17.

[16] B. Nas and A. Berktay, "Groundwater Quality Mapping in Urban Groundwater Using GIS,” Environmental Monitoring and Assessment, Vol. 160, 2010, pp. 215-227. doi:10.1007/s10661-008-0689-4

[17] O. Rimawi, "Hydrochemistry and isotope hydrology of groundwater and surface water in the north-east of Mafraq, Dhuleil, Hallabat, Azraq basin, PhD. Thesis," Techn. University, Muenchen, 1985, p. 240.

[18] E. Salameh, "Over-Exploitation of Groundwater Resources and Their Environmental and Socio-Economic Implications: The Case of Jordan,” Water International Vol. 33, No. 1, 2008, pp. 55-68. doi:10.1080/02508060801927663 